\title{
Sexual behaviour and sexually transmitted diseases in Dutch marines and naval personnel on a United Nations Mission in Cambodia
}

\author{
A P C C Hopperus Buma, R L Veltink, E J C van Ameijden, C H Tendeloo, \\ R A Coutinho
}

\begin{abstract}
Objectives-To determine the sexual risk behaviour and the incidence of sexually transmitted diseases (STD) among Dutch marines and naval personnel during a United Nations (UN) deployment. Methods-Surveillance by post deployment questionnaire, administered to 2289 persons in three successive battalions who served for 6 months on a UN deployment in Cambodia during June 1992November 1993. On site the medical history of all individuals was kept up to date in a database. All personnel received extra education on STD prevention prior to deployment. Condoms were freely obtainable during deployment.

Results-1885 persons $(82 \%)$ handed in the questionnaire of whom 842 (45\%) reported to have had sexual contacts with prostitutes or local population. Being younger and single were independent risk factors for having contact. Out of these 842 persons, $750(89 \cdot 1 \%)$ reported condom use at all times, while $82(9.7 \%)$ reported inconsistent use and 10 persons $(1 \cdot 2 \%)$ reported not to have used condoms. Risk factors for inconsistent and non use were being 40 years or older and a higher number of contacts. From the 832 $(750+82)$ condom users, $248(30 \%)$ reported condom failure. Risk factors for failure were: inconsistent condom use, having had more than six contacts and being in the second battalion. The patient recording database showed 43 STD cases registered in the total population of 2289 persons $(1.9 \%)$.
\end{abstract}

Conclusions-A low STD incidence was found despite a considerable number of reported sexual contacts. The reported condom use was high but the failure rate was considerable and needs further attention.

\section{(Genitourin Med 1995;71:172-175)}

Keywords: military personnel; STD incidence; condom use

\section{Introduction}

During recent years military forces are becoming more involved in United Nations (UN) missions the world over. In 1992-93 Dutch troops took part in the United Nations Transitional Authority in Cambodia (UNTAC). This task brought new challenges for the medical service in preparing and sup- porting these troops. Apart from injuries, we expected to encounter a variety of infectious diseases under the given tropical and primitive circumstances. Reliable recent information on the prevalence of diseases, including STD, in Cambodia turned out to be scarce. ${ }^{1}$ As we expected to be involved in similar UN operations in future and to be better prepared for the medical consequences, we set up a surveillance system to monitor the incidence of acquired injuries and diseases among our personnel in Cambodia. Before departure all received health education about the risks involved in living and working in a tropical country. Special attention was given to sexually transmitted diseases (STD) and condom use because we assumed that the duration of deployment and the destination would form high risks to seek sexual contacts. A great concern in this respect was the increasing human immunodeficiency virus (HIV) threat in South East Asia. ${ }^{2}$

To evaluate the sexual behaviour and the risk to contract STD we undertook a study to determine this behaviour and the incidence of STD in Dutch troops during the Cambodia deployment, on which we report in this article.

\section{Study population and methods}

The study-population consisted of three battalions of Dutch marines and naval personnel who served in Northwestern Cambodia during a UN peace keeping mission. Each battalion was initially planned to stay for a 6 month period. On departure all personnel were medically fit for duty and there were no known cases of STD. Operational periods in Cambodia were spent in camps. Contact with the local population or prostitutes could only take place outside these campsites and varied in accordance with the locations and political tension. Troops had the opportunity to take a two week midterm rest and recuperation leave $(R \& R)$, which was spent in The Netherlands or in hotels in Thailand (Bangkok and Pattaya), Malaysia (Penang) and Singapore. In addition one or two 48 hour leaves could be spent in hotels in Phnom Penh, Battambang and the Thai border town Aranyaprathet.

Before departure to Cambodia everybody received 4 hours of health and hygiene education from the medical service. This included 30 minutes on sexual risk behaviour and STD, in particular the risk of HIV transmission. The importance of condom use was 
Table 1 Predictors of sexual contacts among 1885 Dutch troops during their stay in south east Asia

\begin{tabular}{|c|c|c|c|c|}
\hline Variable & $\begin{array}{l}\text { Total } \\
\text { number }\end{array}$ & $\begin{array}{l}\text { Reported } \\
\text { sexual } \\
\text { contacts (\%) }\end{array}$ & $\begin{array}{l}\text { Odds } \\
\text { ratio }\end{array}$ & $\begin{array}{l}95 \% \\
\text { confidence } \\
\text { intervals }\end{array}$ \\
\hline \multicolumn{5}{|l|}{ Age } \\
\hline$<20$ years & 99 & 69 & 1 & \\
\hline $20-29$ years & 1125 & 51 & $0 \cdot 48$ & $0.31-0.74$ \\
\hline $30-39$ years & 479 & 35 & 0.24 & $0.15-0.39$ \\
\hline \multirow{2}{*}{\multicolumn{5}{|c|}{ Steady sex partner* }} \\
\hline & & & & \\
\hline Yes & 822 & 35 & 1 & \\
\hline No & 314 & 82 & 8.41 & $6.04-11.71$ \\
\hline \multicolumn{5}{|l|}{ Battalion } \\
\hline first & 703 & 39 & 1 & \\
\hline second & 513 & 48 & $1 \cdot 45$ & $1 \cdot 15-1 \cdot 82$ \\
\hline third & 669 & 47 & 1.40 & $1 \cdot 13-1 \cdot 74$ \\
\hline
\end{tabular}

^Data available only in second and third battalion.

stressed but demonstrations on correct use were not given. They all received a booklet Staying healthy in the tropics, ${ }^{3}$ which also contained information on STD. During deployment latex condoms (Durex, Bene-luxe) were freely obtainable and distributed by the medical service. This is common policy in The Netherlands Navy and Marine Corps when abroad.

The medical organisation on site included sickbays at all company locations and a field hospital, all manned by doctors and additional medical personnel. They were given extra theoretical and practical training on STD diagnosis and treatment. In Cambodia STD diagnosis was based on the clinical features and direct microscopical examination (Gram stain and dark field). There were no facilities for culturing or serological testing on site but serum could be sent to The Netherlands. Therapy was given according to standardised treatment regimes. ${ }^{4}$ In Cambodia all diagnoses and treatments were registered in a database (Otello).

During the medical check up, a few days after repatriation, participants were asked to fill out an anonymous multiple choice questionnaire on sexual behaviour during the deployment including the $R \& R$ period. Apart from age we asked for frequency and geographical location of sexual contacts, condom use and failure, contracted STD and treatment. Because of the very small number of

Table 2 Predictors of inconsistent condom use * among 842 Dutch troops during their stay in south east Asia

\begin{tabular}{|c|c|c|c|c|}
\hline Variable & $\begin{array}{l}\text { Total } \\
\text { number }\end{array}$ & $\begin{array}{l}\text { Inconsistent } \\
\text { condom use (\%) }\end{array}$ & $\begin{array}{l}\text { Odds } \\
\text { ratio }\end{array}$ & $\begin{array}{l}95 \% \\
\text { confidence } \\
\text { intervals }\end{array}$ \\
\hline \multicolumn{5}{|l|}{ Age } \\
\hline$<20$ years & 68 & 12 & & \\
\hline $20-29$ years & 576 & 9 & 0.76 & $0 \cdot 34-1.67$ \\
\hline $30-39$ years & 167 & 14 & $1 \cdot 20$ & $0.51-2.83$ \\
\hline$\geqslant 40$ years & 31 & 26 & $2 \cdot 61$ & $0 \cdot 88-7 \cdot 77$ \\
\hline \multicolumn{5}{|c|}{ Steady sex partnert } \\
\hline Yes & 291 & 10 & 1 & \\
\hline No & 258 & 11 & $1 \cdot 19$ & $0.69-2.06$ \\
\hline \multicolumn{5}{|l|}{ Battalion } \\
\hline first & 276 & 12 & 1 & \\
\hline second & 248 & 8 & 0.62 & $0 \cdot 35-1 \cdot 12$ \\
\hline third & 318 & 12 & 0.97 & $0.59-1.58$ \\
\hline \multicolumn{5}{|c|}{ Frequency of contact } \\
\hline 1-3 times & 301 & 7 & 1 & \\
\hline 4-6 times & 150 & 11 & $1 \cdot 80$ & $0.91-3.54$ \\
\hline$>6$ times & 391 & 14 & $2 \cdot 30$ & $1.35-3.93$ \\
\hline
\end{tabular}

^Non use included.

†Available only in second and third battalion. female personnel involved we did not ask for gender. A question on whether they had a steady (sex) partner at home was added to the second and third battalion questionnaires.

Sexual contact was defined as insertive genital contact with prostitutes or local population. Condom failure was defined as condoms tearing or sliding off during sexual contact. In combining frequency of condom use and failure we constructed a new variable, protected sexual contact, defined as consistent condom use without failure. All other combinations were considered unprotected.

We obtained written informed consent from all participants. The Dutch Military Medical Committee gave its ethical approval for this study. Data were univariately analysed using the two tailed chi square test. Multivariate logistic regression was used to determine independent risk factors and to adjust for possible confounding. ${ }^{5} \mathrm{P}$-values of 0.05 or less were considered significant.

\section{Results}

POPULATION CHARACTERISTICS

The study population consisted of 2289 persons, 760,752 and 777 in successive battalion. They spent a total of 11848 person months on deployment in the period June 1992 until November 1993. There were 2283 males and 6 females. The mean age was $28 \cdot 1$ (standard deviation (SD) 7.4 years; range 17-52). The mean stay was $5 \cdot 1$ months (SD 1.1 month; range $0 \cdot 5-9 \cdot 4)$.

We received $1885(82 \%)$ valid questionnaires that were used for analysis. The answer-rates per battalion were 703 (93\%), $513(68 \%)$ and $669(86 \%)$ respectively. The lower response in the second group was due to the fact that one company did not get the questionnaire because of logistical problems. If we were to subtract the number of people in this company $(n=130)$ the answer rate in the second battalion would have been $83 \%$. The age-distribution in this company was the same as in the others. Of the respondents (48\%) preferred to spend their $R \& R$ in The Netherlands. The other part took their leave in South East Asia.

\section{SEXUAL BEHAVIOUR}

From the 1885 persons who handed in the questionnaire, $842(45 \%)$ reported sexual contacts during the deployment, of whom 301 persons $(36 \%)$ had one to three contacts and 541 persons $(64 \%)$ had four or more contacts. In the first battalion 276 persons (39\%) reported having had sexual contact while in the other two battalions this was $248(48 \%)$ and $318(47 \%)$ respectively. Univariate analysis showed that being younger, not having a steady "sex" partner at home and being in the second or third battalion were significantly and positively associated with having had sexual contacts (table 1). Multivariate analysis showed that only the first two variables were independent risk factors. In the group reporting sexual contacts $(n=842)$ we found that in total 750 persons $(89 \cdot 1 \%)$ reported use of 
Table 3 Predictors of condom failure among 832 Dutch troops during their stay in south east Asia

\begin{tabular}{|c|c|c|c|c|}
\hline Variable & $\begin{array}{l}\text { Total } \\
\text { number }\end{array}$ & $\begin{array}{l}\text { Condom } \\
\text { failure (\%) }\end{array}$ & $\begin{array}{l}\text { Odds } \\
\text { ratio }\end{array}$ & $\begin{array}{l}95 \% \\
\text { confidence } \\
\text { intervals }\end{array}$ \\
\hline \multicolumn{5}{|l|}{ Age } \\
\hline$<20$ years & 68 & 24 & 1 & \\
\hline $20-29$ years & 571 & 32 & 1.53 & $0 \cdot 85-2 \cdot 76$ \\
\hline $30-39$ years & 164 & 28 & $1 \cdot 27$ & $0 \cdot 66-2 \cdot 44$ \\
\hline$\geqslant 40$ years & 29 & 10 & $0 \cdot 38$ & $0 \cdot 10-1 \cdot 41$ \\
\hline \multicolumn{5}{|c|}{ Steady sex partner } \\
\hline Yes & 287 & 32 & 1 & \\
\hline No & 255 & 35 & $1 \cdot 15$ & $0 \cdot 81-1 \cdot 65$ \\
\hline \multicolumn{5}{|l|}{ Battalion } \\
\hline first & 273 & 25 & 1 & \\
\hline second & 246 & 33 & $1 \cdot 51$ & $1 \cdot 03-2 \cdot 21$ \\
\hline third & 313 & 31 & $1 \cdot 37$ & $0.96-1.98$ \\
\hline \multicolumn{5}{|c|}{ Frequency of contact } \\
\hline $1-3$ times & 297 & 25 & 1 & \\
\hline 4-6 times & 148 & 32 & $1 \cdot 40$ & $0.91-2 \cdot 17$ \\
\hline$>6$ times & 387 & 33 & 1.47 & $1 \cdot 05-2 \cdot 06$ \\
\hline \multicolumn{5}{|l|}{ Condom use } \\
\hline consistent & 750 & 27 & 1 & \\
\hline inconsistent & 82 & 53 & $2 \cdot 77$ & $1 \cdot 70-4 \cdot 52$ \\
\hline
\end{tabular}

^Available only in second and third battalion.

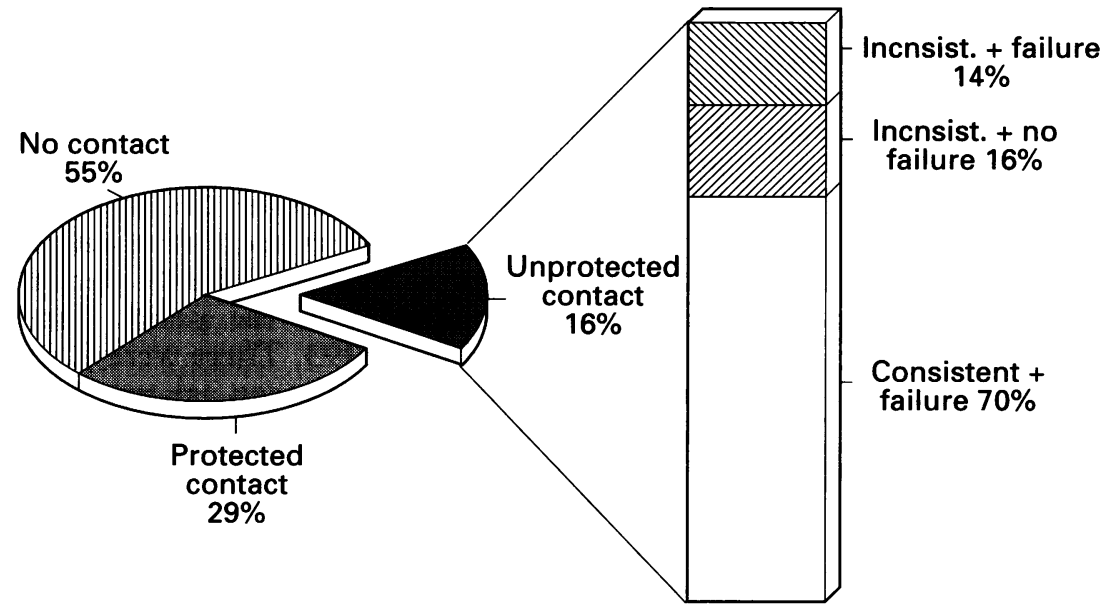

Figure Sexual behaviour in 1885 Dutch troops during their stay in South East Asia.

condoms during all contacts, 82 persons $(9 \cdot 7 \%)$ reported inconsistent use while 10 persons $(1 \cdot 2 \%)$ reported to never have used condoms. There was no association between inconsistent (non use included) condom use and having a steady partner back home.

Table 4 Reported risk factor for STD in 842 Dutch troops during their stay in south east Asia

\begin{tabular}{|c|c|c|c|c|c|}
\hline $\begin{array}{l}\text { Condom } \\
\text { use }\end{array}$ & Failure & $\begin{array}{l}\text { Total } \\
\text { number }\end{array}$ & $\begin{array}{l}S T D \text { attack } \\
\text { rate }\end{array}$ & $\begin{array}{l}\text { Odds } \\
\text { ratio }\end{array}$ & $\begin{array}{l}95 \% \\
\text { Confidence } \\
\text { interval }\end{array}$ \\
\hline $\begin{array}{l}\text { Consistent } \\
\text { Consistent } \\
\text { Inconsistent } \\
\text { Inconsistent } \\
\text { Never }\end{array}$ & $\begin{array}{l}\text { No } \\
\text { Yes } \\
\text { No } \\
\text { Yes } \\
-\end{array}$ & $\begin{array}{r}544 \\
206 \\
40 \\
42 \\
10\end{array}$ & $\begin{array}{r}0 \cdot 4 \\
8 \cdot 3 \\
2 \cdot 5 \\
19 \cdot 0 \\
20 \cdot 0\end{array}$ & $\begin{array}{r}1 \\
24 \cdot 37 \\
6 \cdot 95 \\
63 \cdot 75 \\
67 \cdot 73\end{array}$ & $\begin{array}{c}5 \cdot 58-106 \cdot 44 \\
0 \cdot 62-78 \cdot 31 \\
13 \cdot 03-311 \cdot 84 \\
8 \cdot 46-542 \cdot 47\end{array}$ \\
\hline
\end{tabular}

Table 5 Sexually transmitted diseases in 2289 Dutch troops during their stay in south east Asia *

\begin{tabular}{lllll}
\hline & Battalion 1 & Battalion 2 & Battalion 3 & Total \\
\hline Gonorrhoea & 3 & 11 & 3 & 17 \\
Non gonococcal urethritis & 6 & 5 & 3 & 14 \\
Syphilis & 1 & 1 & - & 2 \\
Herpes genitalis & - & 1 & - & 1 \\
Genital warts & 1 & 1 & - & 5 \\
Pediculosis pubis & - & 2 & - & 2 \\
Scabies & - & 5
\end{tabular}

*As entered into the patient recording database (Otello) June 1992-November 1993.
Significant risk factors for inconsistent condom use were being 40 years or older and a higher number of sexual contacts (table 2). In multivariate analysis both variables appeared independent and significant predictors.

Concerning condom failure, we found that 248 persons $(30 \%)$ of those who used con-o doms $(n=832)$ experienced failure. The strongest univariate risk factor for failure waso inconsistent condom use. Furthermore, significant and positive risk factors were having had more than six sexual contacts and beingo in the second battalion (table 3). All these risk factors appeared independently related in multivariate analysis.

Looking at the total population of $1885 \frac{\overline{\mathrm{c}}}{\mathrm{m}}$ persons, 1043 (55\%) reported not to have had sexual contacts. We found that in the group with sexual contacts $(n=842), 544$ persons $^{\infty}$ reported protected contact at all times. $\overrightarrow{0}$ Unprotected contact was reported by 298 persons. In this group unprotected contact waso

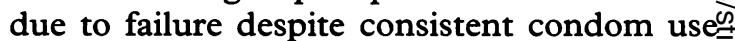
$(70 \%)$, no failure but inconsistent use $(16 \%)$ or the combination failure and inconsistentio use (14\%) (fig).

STD

In the questionnaire 30 out of 1885 personse $(1.6 \%)$ reported to have contracted an $\mathrm{STD}_{\bar{\Phi}}^{=}$ while in South East Asia. Urethral discharge was reported in 18 and genital ulceration ince three cases. The remaining nine persons reported other STD five of which wereo pediculosis. Out of the group that reported not to have had sexual contact $(n=1043$ ) noo one reported an STD.

From the 544 persons who reported protected sexual contact at all times only two응 $(0.4 \%)$ indicated an STD (both pediculosis). In the group reporting unprotected contactso $(n=298) 28$ marines reported STD $(9 \cdot 4 \%) .(n)$ In univariate analysis inconsistent use of con doms or consistent use with failures both proved to be risk factors for STD (table 4).

In our patient database 43 cases of STD were registered, mostly from the second bat-o talion. In the total population of 2289 persons the attack rate is $1.9 \%$, being $1.4 \%, 3.5 \%$ and을 $0 \cdot 8 \%$ per successive battalion. Table 5 shows the numbers and types of diagnosed STD per battalion, indicating a majority of gonorrhoea and non gonococcal urethritis (31 cases). 0 Genital ulceration was found in two syphilis patients and one genital herpes patient. All? pediculosis cases could be traced back to one location (a brothel in Phnom Penh).

\section{Discussion}

The main finding in this study is the low STD rate $(1.9 \%)$, even though the percentage of reported sexual contacts $(45 \%)$ was consider able. The reported consistent condom useo was high $(89 \%)$ but the overall failure rate $(30 \%)$ in this group gives cause for concern.

During the past few years the number of UN missions has increased rapidly and the troops involved are exposed to several health hazards including STD. Over the years studies 
report high incidence for STD among military personnel, in particular when serving away from home and family under stressful circumstances. During the Boer war the STD incidence among British troops was more than $50 \%$, while after leaves in Paris during the first world war a $20 \%$ STD incidence was reported. ${ }^{6}$ A Dutch study in The Netherlands Navy dating back to 1918 mentions an STD attack rate of $37 \%$ among naval personnel stationed in the former Dutch East Indies in $1913 .{ }^{7}$ In that same area over a 3 year period in the late forties a case rate of $16 \%$ was found among Dutch army troops. ${ }^{8}$ Australian troops in Vietnam showed an STD incidence of 27\%.9 An American study among naval personnel and marines during trips to South America, West Africa and the Mediterranean during $1989-1991$ found that $10 \%$ acquired a new STD. ${ }^{10}$ In a British Military Hospital in the tropics investigators found an incidence rate of 56558 per 100000 over one calendar year. ${ }^{11}$ The best comparable study we found was among French troops stationed in Cambodia in 1992. They found an attack rate of $4.9 \%(16 / 326)$ over a 6 month period. ${ }^{12}$

We have no real explanation for the higher STD incidence in the second battalion. They received the same education and the working conditions were similar. Although they stayed a few weeks longer and had one extra short leave compared with the other two battalions, the occurrence of STD did not increase toward the end of their stay. They showed a higher condom failure rate but on the other hand inconsistent condom use was lower.

We ascribe our low STD incidence to the high consistent and overall condom use $(98.8 \%)$ among the study population. It is possible that risk behaviour was underreported but the low STD incidence in our troops supports the reported use of condoms. The American study, mentioned earlier, reports an overall condom use of $93 \%,{ }^{10}$ while in the British Military Hospital population $70 \%$ stated that they did not normally use a condom. ${ }^{11}$ We think that free distribution of condoms and education attributed to the high overall condom use. We took along 24000 latex condoms of which only a small number was left at the end of the deployment period. Based on the information gathered from the questionnaire, our estimate on the number of sexual contacts in the total study population lies between 4000 and 7000 .

Both our education before deployment and the sexual health promotion, given to risk groups and most secondary schools over the last few years in The Netherlands will have contributed to the high condom use. It fits our finding of inconsistent condom use in the age group over 40 years. Finally we realise that our study was conducted at a time of increased awareness in regard to the HIV threat in South East Asia. All personnel had the opportunity to undergo an HIV test vol- untarily and we know that about half our population took the test. For legal reasons the results were confidential and not stored in medical records. As far as we know no one was found to be HIV positive.

Although the use of condoms was high we found the failure rate $(30 \%)$ considerable. One American study showed a failure rate of $27 \%{ }^{13}$ and a British study showed an even higher percentage of condoms splitting or slipping off $(40 \%) .{ }^{14}$ However, both studies show results found among STD clinic visitors. We cannot explain the failure rate in our population since questions on reasons for failure were not included in the questionnaire. One explanation for failure in our population could be the lack of demonstrations on correct condom use during education on prevention of STD. The medical service and the troops themselves thought that this was generally known. Especially in the younger age groups condom use was supposed to be known because of the sexual health education programmes in our country. In future deployments we will pay more attention to the prevention of failure, since consistent condom use alone is not enough to minimise STD. Our findings indicate that certain groups need extra attention.

In conclusion this study shows that with proper education and freely obtainable condoms the risk for acquiring STD among military personnel during deployments can be minimised. More attention must be paid to the prevention of condom failure.

We thank Dr A Leentvaar-Kuijpers for her advice and assistance in setting up the questionnaire and the medical personnel at the Marine barracks in Doorn, without whose support this project would not have been possible.

1 Wilson ME. A World Guide to Infectious Diseases. New York: Oxford University Press 1991;251-257,343

2 Kaldor JM, Effler P, Sarda R, et al. HIV and AIDS in Asia and the Pacific: an epidemiological overview. AIDS 1994;8(suppl 2): S165-72.

3 Smits SP. Hoe blijf ik gezond in de tropen. Amsterdam: Koninklijk Instituut voor de Tropen, 1992.

4 Centers for Disease Control. 1989 Sexually Transmitted Diseases Treatment Guidelines. MMWR 1989: 38(No.S-8).

5 Hosmer DW, Lemeshow S. Applied Logistic Regression. New York: John Wiley \& Sons, Inc, 1989.

6 Adler MW. The terrible peril: a historical perspective on the venereal diseases. $B M \Im$ 1980;281:206-11.

7 Deinse FJH van. Het vraagstuk der venerische ziekten bij de Koninklijke Marine, Leiden: Eduard IJdo, 1918.

8 Doeleman F. The Medical History of an InfantryBattalion of the Royal Dutch Army during three years of active service on the isle of Java. Assen: van Gorcum \& co 1955 . p.132-45.

9 Hart G. Factors influencing venereal infection in a war environment. Br $\mathcal{F}$ Venereal Dis 1974;50:68-72.

10 Malone JD, Hyams KC, Hawkins RE, Sharp TW, Daniell FD. Risk factors for Sexually-Transmitted Diseases Among Deployed U.S. Military Personnel. Sex Transm Dis 1993;20:294-8.

11 Adams EJ, Strike PW, Green AD, et al. Sexually transmitted diseases in transient British forces in the tropics. Genitourin Med 1994;70:94-6.

12 Kaiser E. Prévention efficace le VIH, Etude sur 618 parachutistes en mission outre-mer. Médécine et Armées 1993;21:613-6.

13 Weinstock HS, Lindan C, Bolan G, Kegeles SM, Hearst N. Factors associated with condom use in a high-risk heterosexual population. Sex Transm Dis 1993;20:14-20.

14 Sonnex C, Hart GJ, Williams P, Adler MW. Condom use by heterosexuals attending a department of GUM: attitudes and behaviour in the light of HIV infection. Genitourin Med 1989;65:248-51. 